\title{
Suplementasi Tepung Jagung dalam Ransum Meningkatkan Kualitas Daging Sapi Bali
}

\author{
Ni Nyoman Suryani ${ }^{1}$, I Wayan Suarna ${ }^{2}$, I Gede Mahardika ${ }^{3}$, Ni Putu Sarini ${ }^{4}$ \\ 1,2,3,4 Puslitbang Tumbuhan Pakan, LPPM, Universitas Udayana \\ Email : 1,2,3,4 puslitbangtp@gmail.com
}

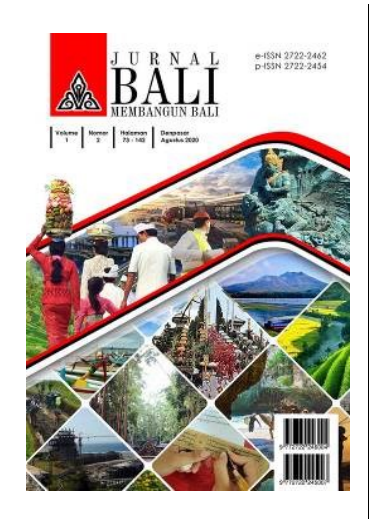

Sejarah Artikel

Diterima pada 23 Juni 2020

Direvisi pada 27 Juni 2020

Disetujui pada 2 Juli 2020

\section{Abstrak}

Tujuan: Studi ini dilaksanakan untuk mengoptimalkan produktivitas sapi bali sehingga mampu menghasilkan daging dengan kualitas yang baik.

Metode penelitian: Percobaan menggunakan perlakuan yang terdiri atas: Perlakuan A: Sapi yang diberikan pakan rumput gajah + konsentrat $1,5 \%$ dari berat badan; Perlakuan B: Sapi yang diberikan pakan rumput gajah $+1,5 \%$ konsentrat dari berat badan dan $1 \mathrm{~kg}$ tepung jagung; Perlakuan C: Sapi yang diberikan pakan rumput gajah + konsentrat $1,5 \%$ dari berat badan dan $1,5 \mathrm{~kg}$ tepung jagung; dan Perlakuan D: Sapi yang diberikan pakan rumput gajah + konsentrat 1,5\% dari berat badan dan $2 \mathrm{~kg}$ tepung jagung. Pakan konsentrat diberikan dua kali pada pagi dan sore hari, sedangkan pakan hijauan diberikan dalam keadaan segar setelah diberikan pakan konsentrat.

Temuan: Hasil penelitian menunjukkan bahwa persentase karkas hasil penelitian ini cukup tinggi yakni mencapai $55 \%$, susut masak daging sapi berkisar antara 33,27 35,49 . Ada kecenderungan meningkatnya daya ikat air dan menurunnya susut masak. Warna, keempukan, dan citarasa daging sapi bali hasil penelitian ini lebih disukai dibandingkan daging sapi import maupun sapi lokal yang dibeli di pasaran.

Implikasi: Sapi bali adalah salah satu komuditas unggulan Provinsi Bali. Kualitas daging sapi bali sampai saat ini masih memerlukan upaya peningkatan. Kualitas daging sapi bali yang dipelihara dengan manajemen yang baik, secara fisik dan hedonik tidak berbeda dengan daging sapi import.

Kata Kunci: sapi bali, tepung jagung, karkas, kualitas daging.

\begin{abstract}
Purpose: This study was conducted to optimize its productivity to obtain premium beef quality.

Research methods: Three treatments were given to twelve noncastrated male bali cattle at the age of two years. Those treatments were A: elephant grass $+1,5 \%$ cattle weight of concentrate, $\mathrm{B}$ : elephant grass $+1.5 \%$ cattle weight of concentrate $+1 \mathrm{~kg}$ corn flour, C: elephant grass $+1.5 \%$ cattle weight of concentrate $+1,5 \mathrm{~kg}$ corn flour and D: elephant grass $+1.5 \%$ cattle weight of concentrate $+2 \mathrm{~kg}$ of corn flour. Cattle were given fresh grass after concentrate twice daily. After 4 months of treatments, all cattle in this study were slaughtered. Carcass percentage, cooking loss, color, tenderness were the meat quality parameters observed and then the meat was hedonic tested to find out taste preferences.

Findings: This study showed that carcass percentage obtained high enough. It was reached 55\%. Cooking loss was 33.27 to 35.49 . There was a tendency that cooking loss increase due to high water content of the meat. Color, tenderness and taste of this beef were more preferable compare to imported beef and bali cattle beef obtained from the local market.

Implications: Bali beef is one of the main commodity from Bali Province. Until now its meat quality require efforts to be improving. Bali beef supplemented with additional corn flour, were able to have physical, chemical and hedonic meat quality equal to imported beef.
\end{abstract}

Keywords: bali beef, corn flour, carcass, meat quality. 


\section{PENDAHULUAN}

Indonesia baru bisa dikatakan sudah berswasembada daging sapi apabila 9095\% kebutuhannya sudah bisa dipenuhi dari produksi daging nasional. Semakin meningkat jumlah penduduk dan semakin meningkat kesadaran masyarakat akan pemenuhan kebutuhan protein hewani, maka semakin meningkat pula kebutuhan akan daging sapi. Namun, sampai saat ini ketersediaan daging nasional masih belum terpenuhi secara mandiri karena baru mampu menyediakan $82,52 \%$ dari kebutuhan (Press Rilis Ditjenakkeswan, 2012) dan sisanya masih mendatangkan dari luar negeri.

Sensus Badan Pusat Statistik (2010) menunjukkan bahwa 99,81\% sapi di Indonesia dipelihara secara tradisional dengan skala kepemilikan 2 - 3 ekor. Hanya $0,0041 \%$ yg dikelola secara profesional dengan kepemilikan ribuan sampai puluhan ribu ekor. Berdasarkan hasil sensus juga, pemeliharaan sapi di Indonesia ada 4 tujuan: 1) pengembangbiakan $76,04 \%$; 2) penggemukan $21,37 \%$; 3 ) pembibitan $2,32 \%$; dan 4) perdagangan $0,27 \%$.

Diwyanto dan Praharani (2010) menyatakan sapi bali merupakan sapi pedaging asli Indonesia dan diakui sebagai breed yang superior karena mempunyai fertilitas dan konsepsion rate yang tinggi yaitu $85,9 \%$ dan persentase beranak $70-81 \%$ (Handiwirawan dan Subandriyo, 2004), serta mampu beradaptasi pada I ingkungan kurang bagus dan efisien menggunakan pakan kualitas jelek. Dari hasil penelitian Arka (1984), diketahui kelebihan yang dimiliki sapi bali adalah kandungan protein dagingnya cukup tinggi $(19,65--21,28 \%)$, kandungan lemak rendah $(2,01-6,86 \%)$ dan tanpa marbling.

Berdasarkan uraian di atas, dapat dikatakan bahwa sapi bali mempunyai nilai strategis, oleh karena itu penting untuk meningkatkan kualitas dan kuantitasnya selain sebagai tulang punggung pemasok daging nasional, juga akan berdampak pada peningkatan keuntungan peternak. Pemerintah saat ini juga sedang mencanangkan program swasembada daging sapi, dan keberhasilan pelaksanaannya akan berdampak pada percepatan tercapainya program swasembada dalam memenuhi kebutuhan daging nasional. Hal penting lainnya yang perlu diperhatikan adalah bahwa meningkatnya kualitas daging sapi bali dapat dicapai apabila dipelihara dengan manajemen yang baik. Mempertimbangkan berbagai hal di atas maka penelitian ini dilaksanakan dengan tujuan untuk menemukan paket teknologi manajemen dan formula ransum untuk sapi sehingga menghasilkan daging dengan kualitas yang baik. 


\section{METODE PENELITIAN}

Penelitian menggunakan 12 ekor sapi bali umur 2 tahun. Masing-masing sapi dipelihara dalam kandang individu. Sapi yang digunakan adalah sapi jantan umur berkisar antara 1,5 - 2 tahun dengan kisaran berat: $209-362 \mathrm{~kg}$. Sapi dipelihara dalam kandang individu yang dikelompokkan berdasarkan berat badan awal.

Pakan yang diberikan terdiri atas berbagai bahan antara lain: rumput gajah tailand, konsentrat, dan tepung jagung. Pemberian ini disesuaikan dengan perlakuan yang diberikan yaitu:

1. Perlakuan $A$ : sapi yang diberikan pakan rumput gajah + konsentrat $1,5 \%$ dari berat badan

2. Perlakuan $\mathrm{B}$ : sapi yang diberikan pakan rumput gajah $+1,5 \%$ konsentrat dari berat badan dan $1 \mathrm{~kg}$ tepung jagung

3. Perlakuan C: sapi yang diberikan pakan rumput gajah + konsentrat $1,5 \%$ dari berat badan dan $1,5 \mathrm{~kg}$ tepung jagung

4. Perlakuan D: sapi yang diberikan pakan rumput gajah + konsentrat $1,5 \%$ dari berat badan dan $2 \mathrm{~kg}$ tepung jagung.

Pakan konsentrat diberikan dua kali pada pagi dan sore hari. Sedangkan pakan hijauan diberikan dalam keadaan segar setelah diberikan pakan konsentrat.

Persentase karkas dihitung dengan cara memotong ternak, kemudian menimbang karkasnya. Persentase karkas adalah perbandingan antara berat karkas dengan berat hidup dikalikan $100 \%$. Kualitas daging meliputi kualitas fisik, kualitas kimia dan uji hedonic. Kualitas fisik meliputi: $\mathrm{pH}$ daging, daya ikat air, marbling, susut masak, warna, tekstur, kekenyalan. Kualitas kimia meliputi kadar protein, lemak, kolagen, sedangkan uji hedonik meliputi penerimaan oleh responden termasuk rasa.

Data yang diperoleh pada penelitian ini dianalisis dengan sidik ragam. Apabila terdapat hasil yang berbeda nyata $(P<0,05)$ antar perlakuan, maka analisis dilanjutkan dengan uji kontras ortogonal pada taraf 5\% (Steel dan Torrie, 1989).

\section{HASIL DAN PEMBAHASAN}

\section{Karkas dan Bagian-bagiannya}

Performans seekor ternak merupakan hasil dari pengaruh faktor genetik dan faktor lingkungan. Seekor sapi yang memiliki genetik bagus tidak akan menunjukkan performans produksi yang baik apabila tidak didukung oleh lingkungan yang baik, begitu juga sebaliknya. Salah satu faktor lingkungan tersebut adalah pemberian nutrisi. Seekor sapi dianggap baik bila menghasilkan karkas dengan kuantitas dan kualitas yang optimal. Parameter penilaian karkas yang umum antara lain persentase karkas 
dan bagian-bagian karkas. Sapi yang memiliki bobot hidup yang tinggi tidak selalu menunjukkan persentase karkas yang tinggi.

Karkas yang berasal dari ternak yang diberi pakan berenergi tinggi mengandung lemak lebih banyak daripada yang diberi pakan berenergi rendah. Peningkatan konsumsi energi akan meningkatkan kadar laju pertumbuhan dan dapat menghasilkan karkas yang lebih banyak. Pada umumnya, energi pakan yang tinggi akan menghasilkan bobot yang lebih berlemak daripada pemberian pakan berenergi rendah pada kurun waktu tertentu (Rahaldo, 2012). Saka et al. (2011) menyatakan bahwa kualitas karkas dipengaruhi oleh jenis ternak, jenis kelamin, pakan dan teknologi pakan, serta penanganan ternak sebelum pemotongan Sementara menurut Soeparno (2005) bahwa pakan sangat berpengaruh terhadap kualitas karkas dan kualitas daging.

Semakin tinggi pemberian tepung jagung menyebabkan semakin tinggi $(P<0,05)$ berat potong ternak penelitian (Tabel 1). Sapi muda yang dipelihara dengan baik akan menghasilkan berat potong yang tinggi. Sapi yang berumur $2-2,5$ tahun yang mendapat penanganan baik terutama pemenuhan akan kebutuhan nutriennya dapat mempercepat pertumbuhan berat badan hariannya. Peningkatan berat badan sapi akan dipercepat lagi dengan pemberian tambahan tepung jagung. Persentase karkas sapi hasil penelitian ini cukup tinggi yakni mencapai 55\%. Persentase karkas sapi bali ini lebih tinggi daripada sapi bali yang dipelihara secara konvensional. Tidak ada perbedaan antara bagian-bagian karkas seperti tenderloin, striploin, dan rump. Berdasarkan informasi dari tukang potong yang selalu bertugas di RPH Mambal menyatakan bahwa sapi hasil penelitian yang dipotong ini merupakan sapi yang berkualitas baik dan yang sangat diminati hotel dan restoran. Hal tersebut dikarenakan kualitas tenderloin yang sangat baik dan merupakan bagian karkas yang paling mahal. Berat tenderloin yang diperoleh per ekor dapat mendekati $5 \mathrm{~kg}$.

Tabel 1. Karkas dan bagian karkas sapi bali

\begin{tabular}{crrrr}
\hline \multicolumn{1}{c}{ Peubah } & A & \multicolumn{2}{c}{ RansumPerlakuan } & \multicolumn{1}{c}{ D } \\
\hline Berat potong (kg) & \multicolumn{1}{c}{ B } & C & \multicolumn{1}{c}{} \\
Karkas (\%) & $331,67 \mathrm{a}$ & $357,33^{\mathrm{ab}}$ & $370,00^{\mathrm{b}}$ & $389,00^{\mathrm{b}}$ \\
\hline Tenderloin (\%) & $54,33^{\mathrm{a}}$ & $55^{\mathrm{a}}$ & $55^{\mathrm{a}}$ & $55^{\mathrm{a}}$ \\
Striploin (\%) & $1,47^{\mathrm{a}}$ & $1,42^{\mathrm{a}}$ & $1,50^{\mathrm{a}}$ & $1,53^{\mathrm{a}}$ \\
Rump (\%) & $3,15^{\mathrm{a}}$ & $3,38^{\mathrm{a}}$ & $3,38^{\mathrm{a}}$ & $3,56^{\mathrm{a}}$ \\
& $1,9^{\mathrm{a}}$ & $1,87^{\mathrm{a}}$ & $1,86^{\mathrm{a}}$ & $2,07^{\mathrm{a}}$ \\
\hline
\end{tabular}

Keterangan: 
Huruf kecil yang sama dalam baris yang sama menunjukkan perbedaan yang tidak nyata $(P>0,05)$
A. Tidak diberikan tepung jagung
B. Diberikan tambahan $1 \mathrm{~kg}$ tepung jagung/e/hari
C. Diberikan tambahan $1,5 \mathrm{~kg}$ tepung jagung/e/hari
D. Diberikan tambahan $2 \mathrm{~kg}$ tepung jagung/e/hari

\section{Sifat Fisik Karkas}
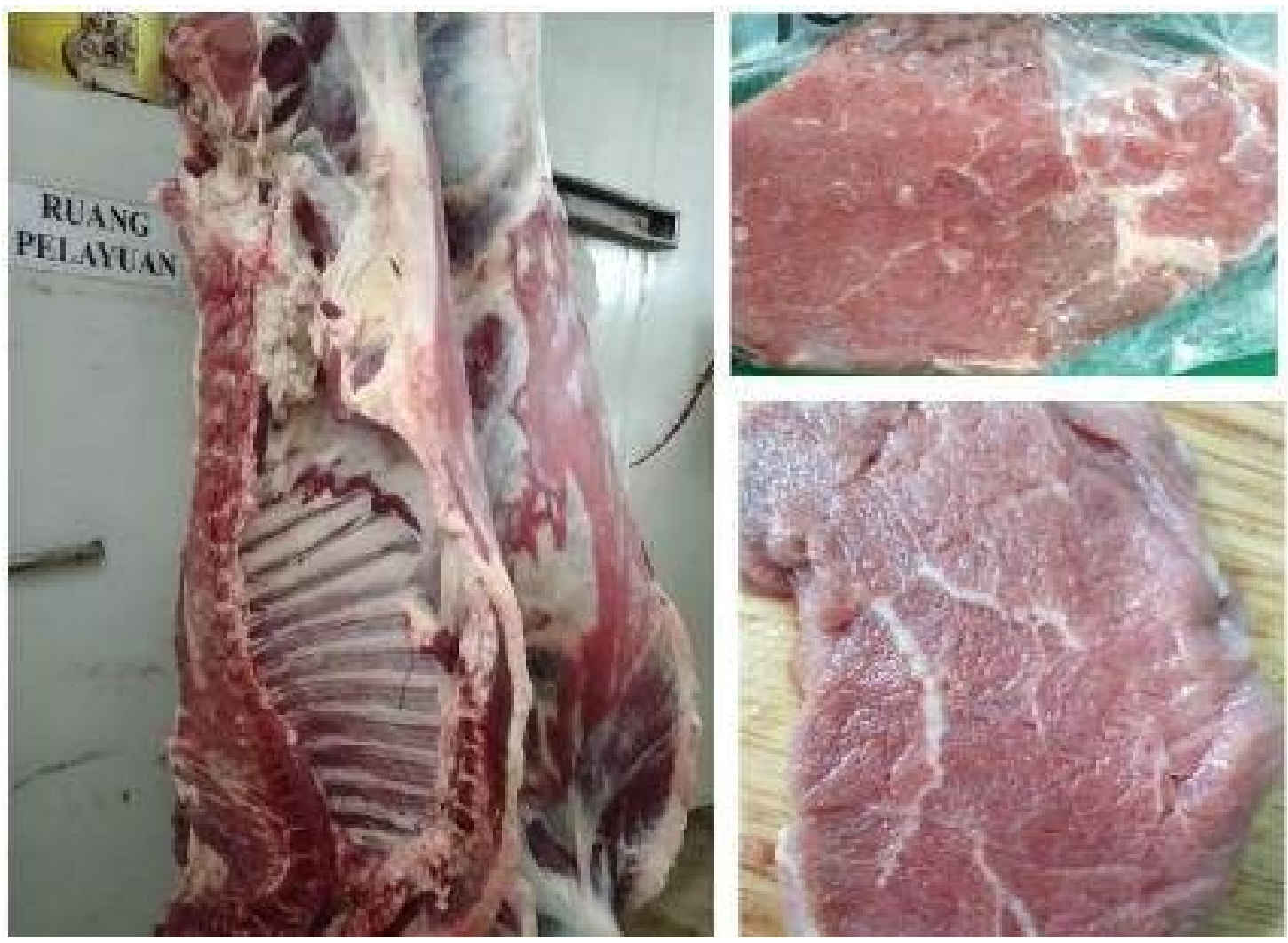

Gambar 1. Karkas dan daging sapi bali hasil penelitian.

Sifat fisik karkas yang meliputi $\mathrm{pH}$, daya ikat air dan susut masak tidak menunjukkan perbedaan yang nyata antara sapi yang mendapat tambahan tepung jagung dengan sapi yang tidak mendapat tambahan tepung jagung (Tabel 2). Susut masak daging sapi pada penelitian ini, berkisar antara 33,27 - 35,49. Ada kecenderungan terjadi penurunan susut masak dengan meningkatnya pemberian tepung jagung. Penelitian Komariah et al. (2009) yang meneliti kualitas daging sapi Brahman, kerbau dan domba mendapatkan bahwa susut masak daging sapi 6 jam setelah dipotong adalah $41,40 \%$. Hasil penelitian ini mendapatkan bahwa kualitas daging sapi hasil penelitian ini lebih baik, karena mempunyai susut masak yang lebih kecil. Obuz et al. (2004) menyatakan bahwa meningkatnya susut masak erat kaitannya dengan serat otot dan penyusutan kolagen. Di samping itu, susut masak erat kaitannya dengan daya ikat air, semakin rendah daya ikat air, maka susut 
masaknya semakin besar. Faktor lain yang juga mempengaruhi susut masak adalah $\mathrm{pH}$. Pada $\mathrm{pH}$ isoelektrik $(5,0-5,3)$ nilai susut masak daging tersebut paling rendah. Yanti (2008) menyatakan bahwa susut masak daging sapi yang baik adalah dibawah $35 \%$.

Hasil penelitian ini mendapatkan bahwa meningkatnya pemberian tepung jagung menyebabkan kecenderungan meningkatnya daya ikat air dan menurunnya susut masak (Tabel 2). Hal ini memberikan indikasi bahwa pemberian tepung jagung pada sapi penggemukan dapat meningkatkan kualitas fisik daging sapi. Kurniawan (2014) dalam penelitiannya mendapatkan bahwa daya ikat air daging sapi 23,67$33,98 \%$. Perbedaan daya ikat air ini dipengaruhi oleh beberapa faktor antara lain: perbedaan breed sapi, umur sapi, tingkat stress, pakan yang diberikan dan $\mathrm{pH}$. Semakin tinggi $\mathrm{pH}$ maka daya ikat airnya juga cenderung meningkat. Penurunan $\mathrm{pH}$ akan menyebabkan denaturasi dari protein daging sehingga menurunkan kelarutan protein yang selanjutnya menurunkan daya ikat air.

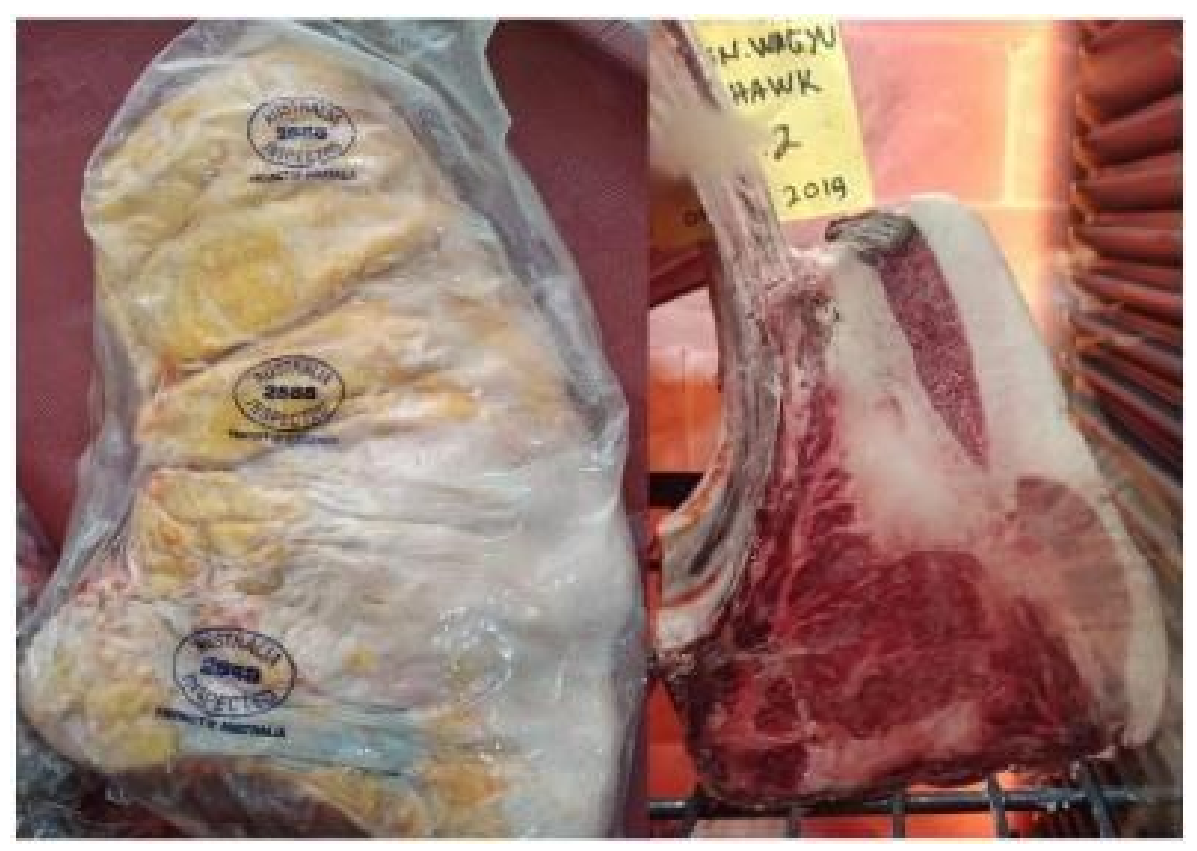

Gambar 2. Karkas daging sapi impor

Tabel 2. Pengaruh penambahan tepung jagung terhadap Sifat Fisik Karkas

\begin{tabular}{|c|c|c|c|c|}
\hline \multirow[t]{2}{*}{ Peubah } & \multirow[b]{2}{*}{ A } & \multicolumn{2}{|c|}{ Ransum Perlakuan } & \multirow[b]{2}{*}{ D } \\
\hline & & B & $\mathbf{C}$ & \\
\hline $\mathrm{pH}$ & $6,41 a$ & $6,33^{a}$ & $6,28^{a}$ & $6,24^{a}$ \\
\hline Daya ikat air (\%) & $35,92^{a}$ & $37,98^{a}$ & $37,17^{a}$ & $38,31^{a}$ \\
\hline
\end{tabular}




$\begin{array}{lllll}\text { Susut masak (\%) } & 35,49^{\mathrm{a}} & 34,83^{\mathrm{a}} & 33,38^{\mathrm{a}} & 33,27^{\mathrm{a}}\end{array}$

Keterangan:

Huruf kecil yang sama dalam baris yang sama menunjukkan perbedaan yang tidak nyata $(P>0,05)$

A. Tidak diberikan tepung jagung

B. Diberikan tambahan $1 \mathrm{~kg}$ tepung jagung/e/hari

C. Diberikan tambahan $1,5 \mathrm{~kg}$ tepung jagung/e/hari

D. Diberikan tambahan $2 \mathrm{~kg}$ tepung jagung/e/hari

\section{Uji Organoleptik}

Uji organoleptik dilaksanakan dengan mengundang sekitar 25 orang panelis yang berasal dari: RPH, ahli daging, ilmuwan, chef, praktisi, masyarakat umum, dan praktisi. Skor yang dipakai adalah 1 sampai dengan 10. Semakin tinggi nilai skor, maka semakin baik penerimaan responden. Pada Tabel 3 tampak bahwa warna daging sapi hasil penelitian lebih disukai dari pada daging sapi import maupun daging sapi lokal. Terhadap test aroma, daging sapi bali penelitian ini lebih disukai dibanding daging sapi import akan tetapi mempunyai angka kesukaan yang sedikit lebih rendah dibandingkan daging sapi bali lokal yang dibeli di pasar tradisional. Keempukan dan citarasa daging sapi bali hasil penelitian ini menunjukkan nilai yang lebih tinggi dibandingkan daging sapi import maupun sapi lokal.
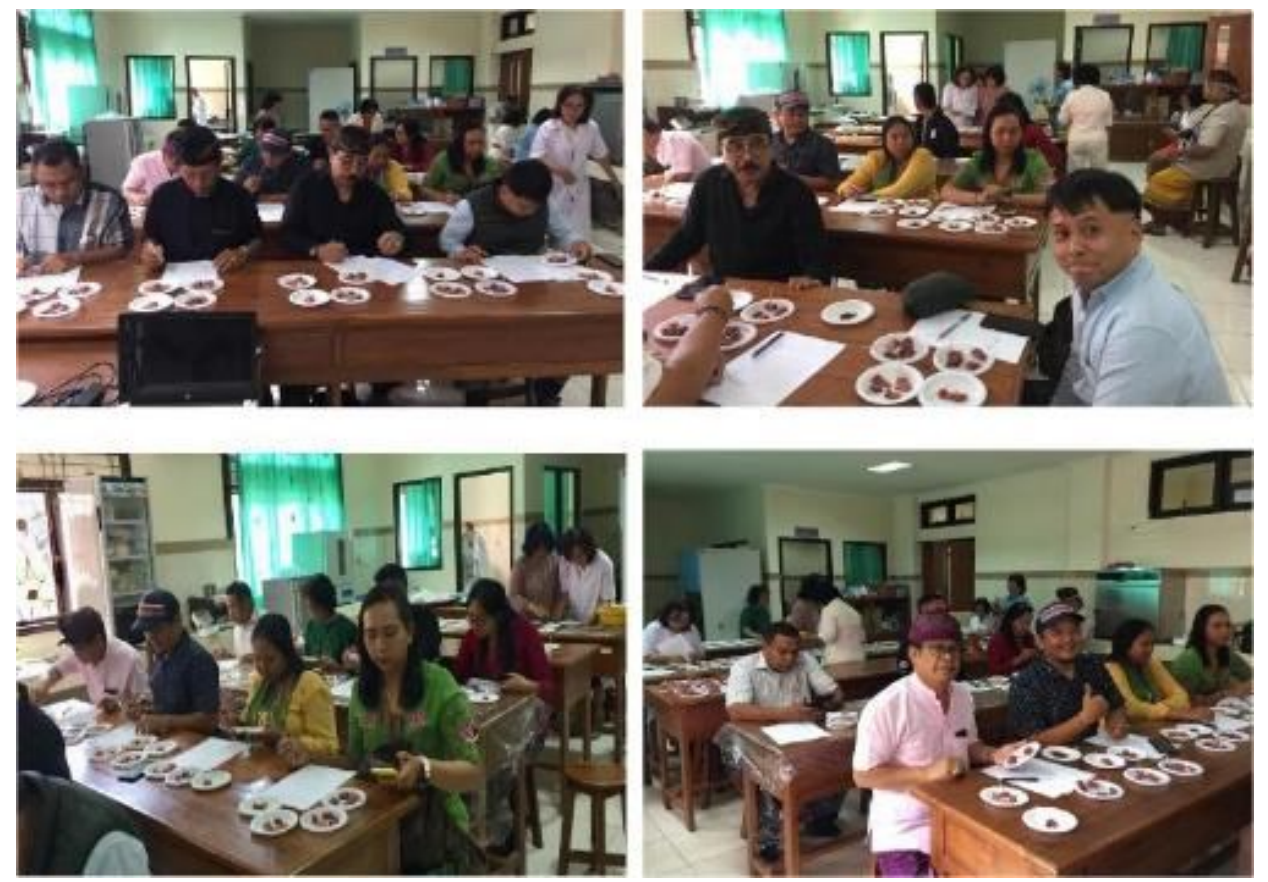

Gambar 3. Pelaksanaan Test Organoleptik di Lab. Mikrobiologi Fapet Unud.

Histologi potongan melintang daging sapi mempelihatkan adanya lipatan lemak dalam daging sapi sehingga dapat memberikan aroma dan joyce daging 
yang lebih baik. Gambar 4 menunjukkan lemak pada tenderloin cukup banyak demikian pula pada rump. Kehadiran lemak yang cukup banyak pada tenderloin dan rump menandakan peningkatan kualitas daging. Kolagen adalah asam amino rantai panjang yang terdiri dari individu asam amino glisin, prolin, hidroksiprolin, dan arginin. Setidaknya ada 16 jenis kolagen dalam tubuh. Komponen ini paling sering ditemukan pada kulit, tulang, dan jaringan ikat tubuh.

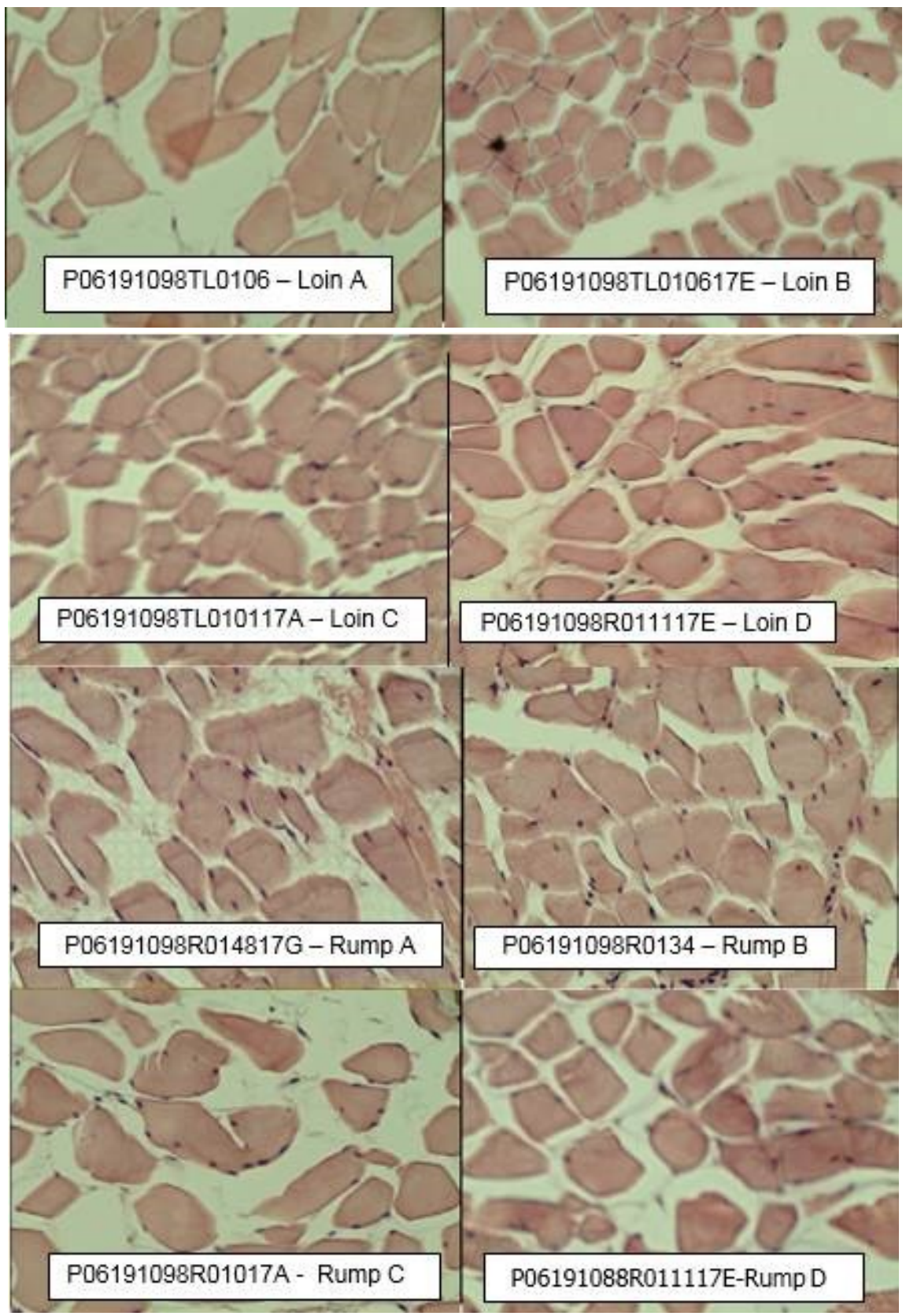

Gambar: 4. Histologi potongan melintang daging sapi bali 
Tabel 3. Hasil Test Organoleptik

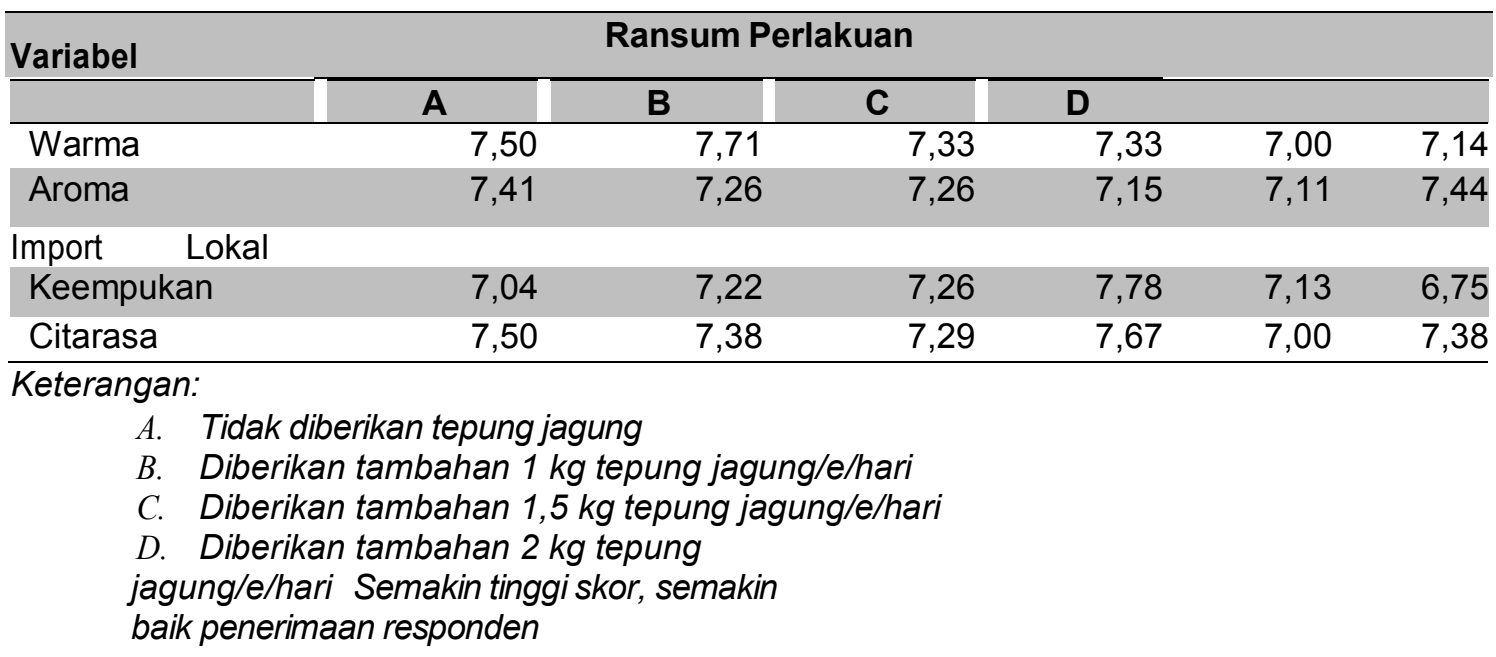

\section{SIMPULAN}

Kualitas daging sapi bali yang dipelihara dengan manajemen yang baik, secara fisik dan hedonik tidak berbeda dengan daging sapi import. Suplementasi tepung jagung meningkatkan berat potong ternak dan keempukan serta cita rasa daging dibandingkan dibandingkan dengan daging import dan daging sapi di pasar local

Program pemeliharaan sapi agar mendapatkan kualitas daging yang baik harus dimulai dengan pemilihan bibit sapi yang baik, pemberian pakan yang memenuhi standar dengan manajemen pemeliharaan yang baik. Untuk mendapatkan kuantitas dan kualitas daging sapi bali yang baik, perlu diberikan pakan dengan kualitas yang baik (Protein Kasar ransum minimal 13\% dan Energi ransum di atas $3000 \mathrm{kkal} / \mathrm{kg}$ ).

\section{DAFTAR PUSTAKA}

Arka, I. B. 1984. "Pengaruh Penggemukan Terhadap Kualitas Daging dan Karkas pada Sapi Bali" (Disertasi). Universitas Pajajaran, Bandung.

Badan Pusat Statistik. 2010. Hasil Sensus Penduduk 2010. Data Agregat Per Provinsi. Badan Pusat Statistik. Jakarta, Indonesia.

Diwyanto, K. dan L. Praharani. 2010. Reproduction management and breeding strategis to improve productivity and quality of cattle. Abstracts International Seminar Conservation and Improvement of World Indigenous Cattle. $3^{\text {rd }}$ $4^{\text {th }}$ September. Udayana University, Denpasar Bali-Indonesia.

Handiwirawan, E. dan Subandriyo. 2004. Potensi dan keragaman sumber daya genetik sapi bali. Wartazoa 14 (3): 107-115. 
134 | Ni Nyoman Suryani, I Wayan Suarna, I Gede Mahardika, Ni Putu Sarini 